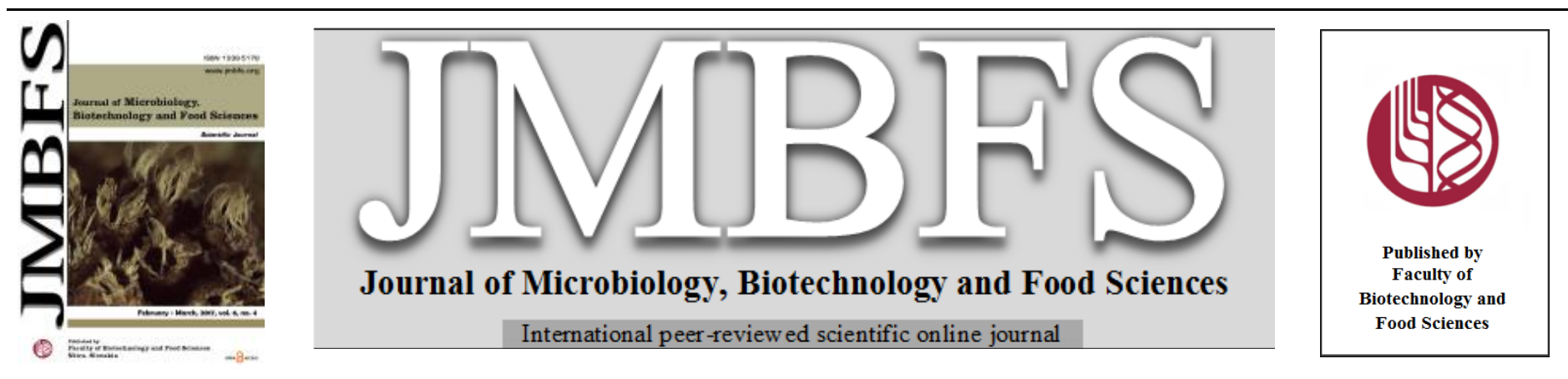

\title{
POLYHYDROXYALKANOATES: BIOSYNTHESIS TO COMMERCIAL PRODUCTION- A REVIEW
}

\section{Loveleen Kaur ${ }^{1}$, Robinka Khajuria ${ }^{1}$, Leena Parihar ${ }^{2}$ and G. Dimpal Singh ${ }^{1}$}

Address(es): Er. Robinka Khajuria,

${ }^{1}$ School of Bioengineering and Biosciences, Lovely Professional University, Phagwara-144411, India.

${ }^{2}$ Department of Botany, Seth G.L. Bihani S.D. (PG) College, Sri Ganganagar-335001, India.

*Corresponding author: robinkakhajuria@gmail.com

\section{ARTICLE INFO}

Received 3. 11. 2016

Revised 5. 1. 2017

Accepted 5. 1.2017

Published 1. 2. 2017

\section{Review}

OPEN $\partial_{\text {ACCESS }}$

\begin{abstract}
The global increase in petroleum prices and the growing concern about the harmful effects of petroleum based plastics has led to a shift from a petroleum based economy to a natural feedstock based economy. One of the major outcomes of this economy shift is the global acceptance of biobased plastics such as Polyhydroxyalkanoates (PHAs) as a replacement for traditional plastics. Even though PHAs have been described as useful polymers due to their intrinsic biodegradability and biocompatibility, the high price has limited their application significantly. The raw material cost has been known to contribute significantly to the manufacturing cost of PHA. Production of PHAs using agro-industrial residues offers an alternative use of low-cost feedstock to produce materials with appropriate physicochemical properties to be used in a broad range of applications. Therefore, much research has been carried out using renewable cheap raw materials such as molasses, lignocellulosic wastes, sewage, industrial by-products, whey etc. to replace the expensive commercial medium, which should reduce the overall production cost. This review highlights various microorganisms, substrates and fermentation strategies used for economical production of PHA.
\end{abstract}

Keywords: Agro-industrial residues, fermentation, microorganisms, polyhydroxyalkanoates, polyhydroxybutyrate

\section{INTRODUCTION}

Since 1950s, synthetic plastics or petroleum based plastics have emerged to be among the most needed materials in our daily life. These plastics are extremely stable in harsh conditions such as attack of chemicals and microbial decomposition, as a result of which they are quite durable, highly resistant and have a very long life span in the environment. Due to their excellent physical and chemical properties, these synthetic plastics have been ruling the commodity market since long. However, in spite of their useful qualities, petroleum based plastics are non-degradable and there are thousands of reports on the increasing environmental problems associated with discarded plastics. National Oceanic and Atmospheric Administration (NOAA) of the United States predicted the presence of high concentration of pelagic plastics and other debris in Central North Pacific Ocean in 1989 (Day et al., 1989). This assembly of plastic debris is now known as the Great Pacific Garbage Patch. According to National Geographic's Encyclopedia, scientists have collected up to 1.9 million bits of plastic per square kilometer of Great Pacific Garbage Patch (Lovett, 2010). Additionally, according to the United Nations' environment program, plastic is responsible for killing a million sea birds and 1, 00,000 marine mammals and turtles a year throughout the World. Increasing environmental awareness amongst the masses has thus, led the scientists to study polymers from alternate sources.

One such class of polymers which has the potential to compete with the synthetic plastics without having an adverse effect on the environment is known as Polyhydroxyalkanoates (PHAs). PHAs are biobased polymers with properties that closely resemble the properties of synthetic plastics. PHA's like synthetic plastics are moldable thermoplastics, and could be tailor-made for a number of applications varying from stiff packaging material to highly elastic materials used as coatings. Moreover the PHAs are completely biodegradable, thus making them a better option as compared to conventional plastics. PHAs are naturally produced by certain microorganisms and transgenic plants. PHB is a type of PHA that is resistant to ultraviolet radiations, water- insoluble and impermeable to oxygen. These attributes make PHB a suitable candidate for use as food packaging material (Aarthi and Ramana 2011). Since the past few decades the bioplastics industry throughout the World has been growing at a very fast pace owing chiefly to:

1. Encouragement of suppliers by retailers to adopt bioplastics for packaging
2. Public concern over the depletion of petroleum based raw materials

3. Greater acceptance by consumers due to eco-friendly nature.

4. Shift in the focus of manufacturing companies towards the development of sustainable raw material sources.

5. Improvement in the properties of bioplastics

6. Increasing government support to bio-based products.

7. Cost-effectiveness of bioplastics.

Inspite of having comparable physical properties to synthetic plastics and being environment friendly, the contribution of bioplastics to market is inconsequential. A major reason for this is low cost efficiency and yield properties of bio-based plastics. The cost of carbon source, fermentation process of the polymer, smal production volumes and downstream processing (particularly purification) all contribute to their high cost of manufacturing. About $50 \%$ of the production costs of the PHA's are attributed to the cost of carbon source. According to a report by 'Bioplastics', global bioplastic market has been growing at a very fast pace over the past few years with an expected production rise to 5.779 million metric tons by 2016. In 2006, one $\mathrm{kg}$ of PHB costed $€ 10-12$ (Kosior et al., 2006) chiefly owing to the raw material and purification costs. However, with advancements in technology, prices as low as $€ 1.50 \mathrm{~kg}^{-1}$ have been achieved by certain companies. A number of studies have been conducted on the use of alternate crude carbon sources such as cornstarch, potatoes, sugarcane etc as discussed ahead. Although use of these carbon sources have led to a decrease in overall cost of production, but with the increasing food insecurity and increment in cost of these crops, the research focus has now shifted to non-edible agricultural residues. This review will discuss different aspects of PHA production highlighting the use of agroindustrial residues.

\section{BIOPLASTICS AND TYPES}

\section{Classification of Bioplastics}

Bioplastics are largely classified on the basis of their biodegradability, type of monomer structure and source of raw materials used. It should be noted by the readers that biodegradability is an inherent property of a material and is not the same as being biobased. Biobased materials can be non-biodegradable while petroleum-based plastics can be biodegradable. 
Based on the structure of monomer, bioplastics can also be divided into three different categories viz. Short Chain Length (SCL), Medium Chain Length (MCL) and PHB copolymers containing monomers of short chain length and medium chain length (SCL-MCL) bioplastics (Tripathi et al., 2012).

A third approach to classification of bioplastics is on the basis of raw material used for their production. Commonly used types of bioplastics are based on cellulose, starch, glucose and oil etc. Specific techniques are employed to convert these feed stocks into bioplastics.

1. Starch based Bioplastics: Various raw materials such as raw starch, modified starch (such as thermoplastic starch), polylactic acid and other starch-derived sugars can be used for the manufacturing of Bioplastics. A number of starch sources such as maize, wheat, potatoes and cassava are in use. Thermoplastic starch is the most widely used bioplastic, accounting for more than 50 per cent of the global bioplastics market. Industrially, starch-based bioplastics are often blended with biodegradable polyesters. Pure starch is used for the production of drug capsules in the pharmaceutical sector because of its property to absorb humidity. By varying the amounts flexibilisers and plasticisers (e.g.sorbitol) the characteristics of starches can be tailored to specific needs. Though these blends are no longer biodegradable, however they display lower carbon footprin compared to conventional plastics. Thermoplastic starch generally represents one of the various constituents of starch based bioplastics. The other constituents consist of water repellent and biologically degradable polymers like polyesteramides, polyester, polyvinylalcohols or polyesterurethanes. Some of the starch based bioplastics include:

a) Polylactic acid (PLA): is one such bioplastics that resembles with fossil fuel based plastics such as polyethylene terephthalate (PET), polyethylene (PE) and polypropylene (PP). PLA possesses an extraordinary stability and is highly transparent. In addition, its production does not require any changes in manufacturing facilities that already exist for the production of petrochemical based plastics. Major raw materials used for production of PLA include starch from crops such as corn, wheat or sugarcane and their fermentation into lactic acid followed by its polymerization. In case of corn, starch is first extracted and converted into dextrose followed by conversion into lactic acid by fermentation. This lactic acid is refined and used for manufacturing of different end-products. By changing the quality and composition of PLA, its biodegradability can be altered. One of the most significant disadvantages of PLA is that it softens at a temperature of about $60^{\circ} \mathrm{C}$ and hence cannot be used for packaging of hot drinks and food. However, co-polymerization with heat resistant polymers and the addition of fillers can provide an alternative.

b) Poly-3-hydroxybutyrate (PHB): is a type of bioplastic produced by bacteria that process glucose or starch. Its characteristics are simila polypropylene, a crude oil derived plastic. PHB is different from most other biodegradable plastics as it is insoluble in water and resistant to hydrolytic degradation. A wide variety of PHA copolymers have been isolated from bacteria including marine freshwater cyanobacteria.

c) Polyethylene (PE): is a fossil based polymer which also can be produced by dehydration of bioethanol produced by fermentation of agro-industrial residues such as sugar cane or corn. Bio-polyethylene shares common chemical and physical properties with traditional polyethylene

2. Oil based bioplastics: Plant oils such as Palm oil, Soyabean oil and Corn oil are desirable raw materials for the production of bioplastics as they are relatively cheaper than most sugars.

a) Poly-3-hydroxyalkanoate (PHA): According to Akiyama et al., 2003, plant oils can provide higher cell biomass and PHA production ( 0.6 to $0.8 \mathrm{~g}$ of PHA per $\mathrm{g}$ of oil) due to their higher carbon content per weight as compared to sugars. Several bacteria are known to produce PHA from plant oils like, Burkholderia cepacia, Pseudomonas aeruginosa, Comamonas testosterone and Cupriavidus necator (Kumar et al., 2011; Marsudi et al., 2008; Fukui and Doi 1998).

b) Polyamide11 (PA 11): is a non-biodegradable biopolymer derived from natural oil such as castor beans. It has a wide range of applications such as use in automotive fuel lines, sports shoes, electrical anti-termite cable sheathing, electronic device components, oil and gas flexible pipes and catheters.

3. Cellulose-based bioplastics: Cellulose is the chief component of plant cell walls which is made of a large number of glucose monomers. Cellulose-based bioplastics are made from chemically-modified plant cellulose such as cellulose acetate (CA). Wood pulp, hemp and cotton are the common sources of cellulose.

4. Lignin-based bioplastics: Paper mill industry produces a large amount of lignocellulosic wastes as a byproduct. Lignin is a naturally occurring complex hydrocarbon and is the chief component of wood. Lignin differs from othe hydrocarbons derived from sugars, starches and cellulose because it contains aromatic rings while polysaccharides contain long molecular chains. After cellulose, lignin is the most abundant renewable carbon source that is readily available, and can substitute many products currently sourced from petrochemical substances.

\section{POLY HYDROXY BUTYRATE (PHB)}

\section{Composition and Occurrence}

The occurrence of Polyhydroxyalkanoates in prokaryotic cells is known to be widespread. They are water insoluble compounds with general structure as shown in the Figure1.They are normally highly crystalline, optically active and possess piezoelectric properties. They are biodegradable, don't not leave any residue and have a melting point of $175^{\circ} \mathrm{C}$. The melting point $\left(\mathrm{T}_{\mathrm{m}}\right)$, crystallinity and glass transition temperature $\left(\mathrm{T}_{\mathrm{g}}\right)$ depend on the composition of the product (Madison and Huisman 1999). One of the most common types of polyhydroxyalkanoates is PHB. PHA's are thermoplastic polymers that are highly viscous at higher temperatures and thus can molded into desired shapes. The application of PHB blends varies from the fabrication of glues to hard rubber. Wide varieties of bacteria are capable of synthesizing PHA as intracellular carbon and energy storage materials (Doi 1990). These polyesters are accumulated as a result of limiting bacterial growth and supplying an excess amount of a carbon source (Chenyu et al., 2012). Some reports suggest that prokaryotic organisms. However, PHB is brittle and hence needs to be synthesized as copolymers of 3 hydroxybutyrate and other hydroxyalkanoates with a relatively low molecular weight and melting point (Fukui and Doi 1998).

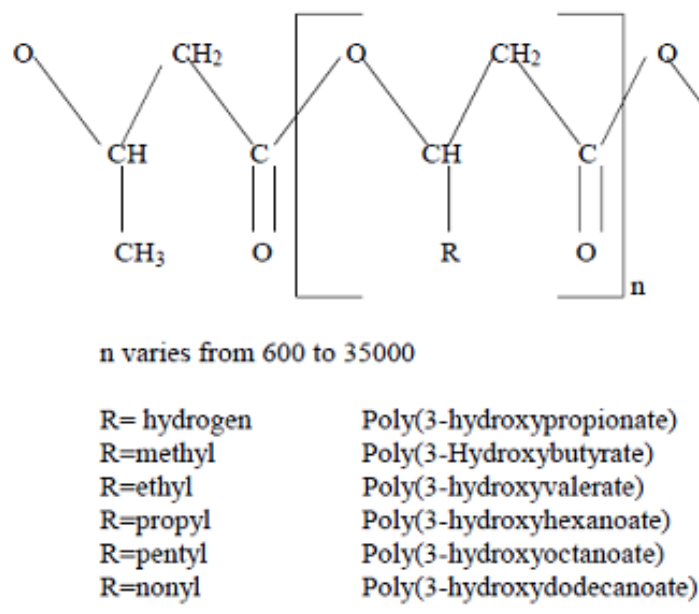

Figure1 General structure of PHA (Lee, 1996a)

\section{Synthesis of Bioplastics}

The Polyhydroxyalkanoic acids, especially PHBs are prepared by many prokaryotes and some eukaryotes in adverse or stress conditions, mainly in nutrient limited conditions. Bacterial genome contains cluster genes for PHA and other proteins related to the metabolism of PHA (Rehm 2003). The genes for class I PHA synthase (phaC), $\beta$-ketoacyl-COA thiolase (phaA) and NADPdependent acetoacetyl-CoA reductase $(\mathrm{phaB})$ constitute the pha $\mathrm{CAB}$ operon (Peoples and Sinskey 1989).In order to synthesize PHB, two molecules of acetyl-CoA condense to form acetoacetyl-CoA. This reaction is catalyzed by $\beta$ ketoacyl-COA thiolase. Subsequently an enzyme named acetoacetyl-CoA reductase reduces acetoacetyl-CoA to (R)-3- hydroxybutyryl-CoA which is then used as a monomer to polymerize PHB by PHB synthase (Figure 2) (Rehm 2003; Madison and Huisman 1999).

Gouda et al., (2001) also found that environmental stresses such as carbon and nitrogen limitation favor the synthesis of PHAs. A possible explanation to the accumulation of PHA under nutrient limiting conditions can be attributed to the inhibition of enzyme $\beta$-ketothiolase by CoA-SH. In conditions of oxygen limitation, the final electron acceptor is lacking, leading to an increased $\mathrm{NADH} / \mathrm{NADH}^{+}$ratio. As a result, many acetyl-CoA molecules cannot enter the TriCarboxylic Acid (TCA) cycle resulting in a decreased CoA-SH concentration $\beta$-ketothiolase is not inhibited anymore and can direct acetyl-CoA molecules to PHA production (Vollbrecht and Schlegel 1979).

Moreover, nitrogen or phosphate limitation results in a reduced activity of anabolic pathways leading to ATP excess which causes acetyl CoA accumulation leading to PHA production in a manner similar to that for oxygen limitation. It has however been observed that complete depletion of a nutrient causes growth cessation resulting in a decreased PHA storage capacity (Khanna and Srivastava 2005) 
Glucose

Acetoacetyl-CoA reductase

Figure 2 Biosynthesis of Polyhydroxy Butyrate

\section{Microorganisms used for PHB production}

Microorganisms belonging to different groups including eubacteria, cyanobacteria, and archaebacteria along with eukaryotes have been found to produce varying amounts of bioplastics depending upon their nutritional and environmental conditions. Bioplastics derived from transgenic plants are also quickly gaining importance. The next section aims to give an overview of the microorganisms capable of synthesizing PHBs.

\section{Eubacteria}

Lemoigne, a French scientist for the first time in the year 1925 reported accumulation of PHB in the form of cytoplasmic inclusions in Gram positive bacterium Bacillus megaterium. Thereafter, a number of bacterial strains among archaebacteria (Doi 1990), Gram positive (Findlay and White 1983), Gram negative bacteria (Shah, 2014) and photosynthetic bacteria (Hassan et al., 1997) including cyanobacteria (Jau et al., 2005) have been found to be associated with PHB accumulation. Most PHA synthesizing bacteria have been reported to belong to pseudomonad, coryneform, and bacillus groups which include Pseudomonas, Bacillus, Citrobacter, Enterobacter, Klebsiella and Escherichia (Arshad et al., 2007). PHB production is widespread in nitrogen fixing organisms like Rhizobium, Azotobacter beijerinckii, A. macrocytogenes, A. vinelandii (Tombolini and Nuti 1989; Senior et al., 1972; Stockdale et al., 1968; Page and Knosp 1989). Bacteria used for PHA production are classified into two groups depending on the culture conditions favoring PHA accumulation: The first group comprises of bacteria that require excess carbon source and limitation of essential nutrients such as oxygen and nitrogen for the efficient synthesis of PHA. The representative bacteria belonging to this group include $C$. necator, Protomonas extorquens and P. oleovorans.

The second group includes bacteria that can accumulate PHA during exponential phase and do not require nutrient limitation. Some of the bacteria included in this group are Alcaligenes latus, Azotobacter vinelandii and recombinant E. coli harboring the PHA biosynthetic operon of $C$. necator (Khanna and Srivastava 2005). Culture conditions for PHA biosynthesis are an important criteria for the development of cultivation techniques for large scale production of PHA.

In addition to the above mentioned microorganisms, methylotrophs have also been found to produce PHB but give a low yield (Suzuki et al., 1986) Recombinant microorganisms, in particular recombinant E. coli, containing PHA biosynthesis genes from A. eutrophus has been able to accumulate high amounts PHA (80-90\% of the cell dry weight) (Lee 1996a). Nutrient limitation is not required for the synthesis of PHB by recombinant $E$. coli strains which depend on the available amount of acetyl-CoA. PHA production in recombinant $E$. coli has many advantages: the bacterial cells grow really fast to a high cell density which results in high productivities, a large amount of polymer is usually accumulated, several inexpensive carbon sources can be utilized, the PHA can be easily purified (Hahn et al., 1995) and there is no depolymerase system in recombinan E. coli that can break down the synthesized polymers (Lee, 1996a). On the other hand, PHA production by recombinant $E$. coli implies a very high oxygen demand during the high cell density culture of recombinant $E$. coli. This major drawback should be tackled in order to make the process economically feasible.

\section{Cyanobacteria}

Cyanobacteria are also known to accumulate PHA by utilizing $\mathrm{CO}_{2}$ and sunlight as carbon and energy sources. These oxygen-evolving photosynthetic bacteria naturally possess PHA synthase enzyme (Sudesh et al., 2000). However, till date only PHB homopolymer has been identified in most cyanobacteria. Among the various cyanobacteria that are capable of synthesizing PHA, Spirulinapla tensis UMACC 161 (Jau et al., 2005) and Synechocystis sp. PCC6803 (Sudesh et al., 2001) can accumulate PHB upto $10 \%$ of the dry cell weight. Synechococcus sp. MA19 and Nostoc muscorum have been reported to produce PHB under phosphate limited conditions (Saharan et al., 2014). A study showed that Nostoc muscorum could produce PHB five times higher under mixotrophy, chemoheterotrophy with nitrogen-limiting state than what was produced under photoautotrophic conditions (Sharma and Mallick, 2005). Use of Cyanobacteria ability to produce PHB with energy obtained from sunlight can result in reduction of cost and $\mathrm{CO}_{2}$.

\section{Archaea}

Haloarchaeal strains do not require strict sterile conditions because of the high salt concentrations required in their growth medium to maintain cell wall stability. This makes cultivation more convenient and easier as compared to eubacterial strains. Moreover, cell walls of haloarchea easily lyse in the absence of salt, especially in distilled water; thus enabling the recovery of PHB and poly(3-hydroxybutyrate-co-3-hydroxyvalerate) from extreme halophiles much more easy and economical (Lillo and Rodriguez-Valera 1990, Han et al., 2010). A number of haloarchaeal genera, viz., Haloferax, Haloarcula, Haloquadratum, Halorubrum, Halobiforma, Halorhabdus, Halalkalicoccus, Halobacterium Natrianema, Halostagnicola, Natrinema, Natronobacterium, Natronorubrum, Haloterrigena, Halopiger, and Halococcus have been reported to produce different types of PHA's (Tekin et al., 2012).

\section{Eukaryotes}

Eukaryotic cells are not known to synthesis PHB, though it has been reported that yeast and some other eukaryotic cells do contain small amounts of low molecular mass PHBs which function as complexes with polyphosphates in membrane transport. Moreover, production of PHBs especially in plants through genetic engineering is being evaluated as a potentially inexpensive alternative to prokaryotic production (Madison and Huisman 1999). PHB production has been reported in Saccharomyces cerevisiae, S. diastaticus, Candida krusei, C. tropicalis, Kloeckera apiculata, Kluyveromyces africans, K. lactis, Rhodotorula glutinis etc.

Scientists are striving to come up with high PHB and related bioplastic producing strains of bacteria as well as eukaryotes. The importance of investigating novel strains lies in the possibility of replacing well-known industrial production strains with new ones, aspiring to a more productive and efficient polymer production process.

\section{Production of PHB from Agro - industrial residues}

The growing concern about the harmful effects of plastics has given impetus to the search of biodegradable alternatives which can compete with the petrochemical based plastics being used worldwide currently. However to produce an economically viable biodegradable plastic, it is necessary to focus on the cost efficiency and yield properties in respect to the production of synthetic plastics based on petrochemicals. The substrate and recovery costs in PHB production by fermentation are very high, making their use unattractive. Carbon source for PHB production accounts for up to $50 \%$ of the total production costs (Shivkumar 2012). One of the ways to cut down the production cost for bioplastic is the use of cheap, readily available industrial and agricultural waste as carbon and nitrogen source. The following section discusses the various agriindustrial residues reported to have been used in the production of PHB's:

\section{Molasses}

It is a viscous by-product produced during refining of sugarcane, grapes, or sugar beets into sugar. It is extensively used as a carbon source in industrial scale fermentations due to its relatively low price and abundance (Zhang et al., 1994). In time 1992, for the first Page reported the accumulation of PHB by Azotobacter vinelandii UWD on sugar beet molasses achieving PHB concentration of 19 to 22 $\mathrm{g} / \mathrm{L}$. Chen and Page (1997) improved the PHB production $(36 \mathrm{~g} / \mathrm{L})$ using a twostage fermentation strategy by A. vinelandii UWD. Albuquerque et al., (2007) on the other hand reported a three-step fermentation strategy for the production of PHAs from cane molasses. Step I was designed to allow fermentation of molasses into organic acids, followed by initiation of PHA accumulation in step II and eventually PHAs were produced using batch fermentation. Bengtsson $\boldsymbol{e} t$ al., (2010) further investigated PHAs synthesis using fermented molasses and a consortium of microorganisms. The PHA yields were in the range of 0.47 to 0.66 C-mol PHA per C-mol of total carbon substrate. Khardenavis et al., (2007) reported PHB accumulation of up to $60 \%$ by waste activated sludge using molasses spentwash as substrate. Pseudomonas aeruginosa has also been reported to utilize cane molasses for the production of PHB in submerged fermentation processes (Tripathi et al., 2012). Naheed et al., (2012) reported the production of PHB using sugar cane molasses by Enterobacter $s p$. and Enterobacteriaciae. Chaijamrus and Udpuay (2008) investigated PHB 
production using B. megaterium ATCC 6748. A maximum of 43\% PHB on cell dry weight was obtained using a feed containing $4 \%$ sugar cane molasses and $4 \%$ corn steep liquor (CSL). Similar PHB yields have been reported by various groups using different strains of B. megaterium (Gouda et al., 2001; Kulpreecha et al., 2009; Ghate et al., 2011).

Besides sugar beet molasses and sugar cane molasses, media based on soy molasses (with high sucrose content) have also been used for PHA accumulation in. Solaiman et al., (2006a) attempted to produce mcl-PHA from soy molasses using Pseudomonas corrugate and achieved a yield of 5-17\% of PHA's such as 3-hydroxyl-dodecanoate, 3-hydroxyl-octanoate and 3-hydroxytetradecenoate. Conversion of saccharides in soy molasses into PHA has also been reported in Bacillus. sp CL1 with a PHA accumulation of up to $90 \%$ of CDW (Full $\boldsymbol{e t}$ al. 2006). Law et al., (2001) reported isolated Bacillus strains, HF-1 and HF-2 capable of synthesizing PHB from hydrolyzed soy and malt wastes. Hameiah $\boldsymbol{e}$ al., (2013) reported PHB production of $0.412 \mathrm{mg} / 50 \mathrm{ml}$ and $0.367 \mathrm{~g} / 50 \mathrm{ml}$ by Lactobacillus acidophilus and Bacillus thuringiensis respectively using date molasses as substrate.

\section{Whey and whey hydrolysates}

It is a by-product of diary and cheese industry that constitutes of the watery portion collected after the separation of fat and casein from whole milk. Cheese whey is normally produced in volumes almost equal to the milk processed in cheese manufactories. The disposal of whey therefore causes serious pollution problems in the surrounding environment due to its enormous biochemical oxygen demand. Lee et al., (1997) constructed different recombinant Escherichia coli strains expressing Cupriavidus necator phaC2 gene for the production of PHB from whey, out of which one isolate grew up to $5.2 \mathrm{~g}$ cell dry weight per Liter (CDW/L), $81 \%$ of which was PHB. Ahn et al., (2000) used a similar recombinant $E$. coli strain CGSC 4401 and a whey solution, achieving a yield of 96.2 $\mathrm{g} \mathrm{PHB} / \mathrm{L}$ in 37.5 hours. Besides recombinant E. coli, the potential of PHA synthesis from whey has also been exploited using various common PHA producing bacteria, such as Ralstonia eutropha DSM545 (Marangoni et al., 2002), Pseudomonas hydrogenovora (Koller et al., 2008), Thermus thermophilus HB8 (Pantazaki et al., 2009) and wild strains, such as Methylobacterium sp. ZP24 (Nath et al., 2008), Hydrogenophaga pseudoflava DSM1034 (Koller et al., 2011).

Povolo and Casella (2003) reported the production of PHA directly from cheese whey permeate by Paracoccus denitrificans DSM 413, Sinorhizobium melilot 41. Thermus thermophilus HB8 (DSM 579) was reported to utilize lactose from whey-based media for the synthesis of polyhydroxyalkanoates under nitrogen limitation (Pantazaki et al., 2009). Baei et al., 2010 reported the production of poly-3(HB-co-27\%-HV) from whey hydrolysate using Azohydromonas lata DSM 1123. Bacillus megaterium CCM 2032 was shown to accumulate more than $50 \%$ of its biomass (w/w) in optimized whey media (Obruca et al., 2011).

Fermentation strategies for the production of PHB from whey by recombinant Escherichia coli strain CGSC 4401 harboring the Alcaligenes latus PHA biosynthesis genes were developed. This recombinant E.coli was reported to accumulate $96.2 \mathrm{~g} / \mathrm{liter}$ of PHA in $37.5 \mathrm{~h}$ of incubation. PHAs production by recombinant Escherichia coli (DH10B and JM10), harboring the structural genes of the polyhydroxyalkanoate synthases of Pseudomonas aeruginosa, using hydrolyzed corn starch and soybean oil as substrate, cheese whey as supplement and acrylic acid as fatty acids $\beta$-oxidation inhibitor has also been reported (Fonseca and Antonio 2006). Hameiah et al., (2013) reported PHB production $(0.337 \mathrm{~g} / 50 \mathrm{ml})$ by $B$. subtilis using whey after an incubation period of 4 days. PHB yield of $25 \%$ and $28 \%$ was obtained when $R$. elti and $R$. stutzeri were grown in medium containing whey as carbon source (Belal 2013). B. thuringenesis IAM12077 has been reported to utilize whole cheese whey and whey supernatant for the accumulation of PHB. PHB yield of $3.99 \mathrm{~g} / \mathrm{L}$ and $3.3 \mathrm{~g} / \mathrm{L}$ was obtained in cheese whey and whey supernatant respectively (Shivkumar 2012). David $\boldsymbol{e t}$ al. (2013) reported a PHB yield of $62 \%$ by Azotobacter chrooccum using whey as substrate.

\section{Lignocellulosic materials}

Significant increase in food prices in the recent years and growing food insecurity has brought the usage of food products in bulk biochemical and biofuels production under scrutiny, forcing the industrial biotechnology development to its focus on to the utilization of non-food biomass, such as lignocellulosic raw materials (Lin et al., 2012). Lignocellulosic biomass consists of 30-50\% cellulose, $20-50 \%$ hemicellulose and $15-35 \%$ lignin. Cellulosic biomass is inedible therefore its usage is not in direct competition with food or animal feed production. But one of the main drawbacks in the use of lignocellulosic raw materials for the production of PHAs is the recalcitrant nature of lignocellulose. Therefore, pretreatment/hydrolysis steps are required to generate the sugar feed stocks that can be metabolized by microbes to produce the bioplastics. In an earlier report in 1990s, Bertrand et al., (1990) showed that Pseudomonas pseudoava was able to grow on the hemicellulosic fraction of poplar wood until $30 \%$ of hydrolysate concentration producing 17 to $22 \%$ PHB. Keenan et al., (2006) used Burkholderia cepacia ATCC 17759 to produce 1.3-4.2g PHBV/L using xylose with levulinic acid as a precursor for HV monomers

Among various agricultural residues, wheat straw is one of the most abundant biomass that can be used as a cheap carbon source for the production of bioplastics. Van-Thuoc et al., (2008) reported the use of wheat bran for the production of PHB by Halomonas boliviensis. Wheat bran was hydrolyzed by a crude enzyme preparation from Aspergillus oryzae NM1 to provide a mixture of reducing sugars composed mainly of glucose, mannose, xylose and arabinose. Growth of Halomonas boliviensis using wheat bran hydrolysate in the medium led to a PHB content of $34 \mathrm{wt} \%$. PHB yield of $64 \%$ was achieved by $A$. chroococcum using wheat bran as a substrate (David et al., 2013). In another report, PHB content of $68 \%$ was achieved by B.sphaericusNCIM5149 when grown on a media containing wheat bran (Ramadas et al., 2009). Cesario et al., (2014) reported the production of PHB by Burkolderia sacchari DSM17165 using wheat straw hydrolysates. B. sacchari metabolized glucose, xylose and arabinose, the main sugars present in wheat straw hydrolysates giving a PHB yield of $0.18 \mathrm{~g} / \mathrm{L}$. Latha et al., (2013) reported the production of PHB using wheat bran by $P$. aeruginosa, $P$. alcaligenes, $P$. cereus, $P$. fluorescens. While maximum $\mathrm{PHB}$ production of $10 \mathrm{~g} / \mathrm{L}$ was observed in case of $P$. aeruginosa, the other strains exhibiting PHB production varying from $0.4-0.9 \mathrm{~g} / \mathrm{L}$.

Besides wheat bran, there are several reports on the use of rice bran for the production of PHA's. Latha et al., (2013) also reported the ability of Pseudomonas sp. to utilize rice bran and saw dust for PHB production. $P$. aeruginosa accumulated maximum $\mathrm{PHB}$ amount in both the substrates (1.4and $1.01 \mathrm{~g} / \mathrm{L})$. Extruded rice bran $(\mathrm{ERB})$ has been used as carbon sources for the production of PHB by an archaea, Haloferax mediterranei. By using ERB as substrate cell PHA concentration of $77.8 \mathrm{~g} / \mathrm{L}$ and PHA content of $55.6 \mathrm{wt}$. \% was obtained in repeated fed-batch fermentation (Huang et al., 2006). $R$. elti and $P$. stutzeri have been reported to achieve PHB yield of 16.7 and $14.9 \%$ respectively using rice straw hydrolysates (Belal 2013). Shivakumar (2012) reported PHB accumulation by $B$. thuringiensis IAM 12077 on different carbon sources like wheat bran $(0.07 \mathrm{~g} / \mathrm{L})$, wheat germ $(0.14 \mathrm{~g} / \mathrm{L})$, rice bran $(0.21 \mathrm{~g} / \mathrm{L})$ and ragi bran $(0.32 \mathrm{~g} / \mathrm{L})$. In addition to wheat and rice bran, several other agricultural residues have also been evaluated for the production of PHB. Jawar stem, a waste product after harvesting Jawar crop (Sorghum bicolor), usually used as cattle feed or as fuel in rural areas contains moderate amount of sugar. Ghate $\boldsymbol{e t}$ al., (2011) reported the use of hydrolyzed jawar stem for PHB production by B. subtilis and B. cereus $(0.034$ and $0.049 \mathrm{gm} / \mathrm{L})$. Coir pith hydrolysates have also been reported to be used as alternate carbon source for PHB production by Azotobacter beijerinickii. Production of PHB $(2.4 \pm 0.2 \mathrm{~g} / \mathrm{L})$ was maximized at $\mathrm{pH} 6.5$ with 3\% coir hydrolysates (Sathesh Prabu and Murugesan 2010).

Patel (2014) reported the ability of $P$. aeruginosa to utilize Rice husk, Cotton seed husk, Walnut shell and Corn cob meal for the production of PHB. Preeti et al., (2012) reported $42 \%$ PHA production from bacteria isolated from soil which could metabolize jambul seed (Syzygium cumini). Saha et al., (2013) used candy factory waste and fruit processing factory waste as substrates for PHA production by Azotobacter chroococcum MAL-201.They obtained PHA accumulation of 40.58 and $22.40 \%$ on candy factory waste and fruit processing factory waste respectively. Oil palm empty fruit bunch (OPEFB), contains abundant cellulose and hemicelluloses and can be used as a renewable resource for fuel and chemical production. Zhang et al., (2013) reported the use of OPEFB derived sugars to produce polyhydroxybutyrate (PHB) Bacillus megaterium R11. It was observed that B. megaterium could accumulate PHB up to $51.3 \%$ of its cell dry weight $(\mathrm{CDW})$ from both glucose and xylose.

\section{Glycerol}

Glycerol is the main by-product of the biodiesel industry with about $10 \%$ (v/v) of the volume of biodiesel. Due to the high volume co-production of glycerol, the world market price of glycerol has dropped rapidly making this by-product, a potential substrate for microbial production of PHAs (da Silva et al., 2009). Pseudomonas putida KT2442 has been reported to produce mcl-PHA from glycerol (Solaiman et al., 2006b). Bormann and Roth (1999) demonstrated the production of PHB from glycerol and casein hydrolysates as carbon and nitrogen sources, by using Methylobacterium rhodesianum and $C$. necator, which produced up to $50 \%$ and $65 \%$ PHB in 45 h, respectively. Ashby (2005) investigated PHA synthesis by Pseudomonas oleovorans NRRL B-14682 and Pseudomonas corrugata 388. Sujatha and Shenbagarathai (2006) constructed a recombinant E. coli strain with the phaC1 gene from Pseudomonas sp. LDC-5 which gave a yield of $3.4 \mathrm{~g}$ PHAs/L on glycerol and fish peptone derived medium. Ashby et al., (2004) used crude glycerol, derived from a soy-based biodiesel production site, for PHA production using $P$. oleovorans NRRL B14682 and $P$. corrugata 388. Promising results were published by Cavalheiro $e$ al., (2009), in which $C$. necator DSM 545 was cultivated up to $68.8 \mathrm{~g} \mathrm{CDW/L}$ on waste glycerol. Zhu et al., (2010) reported that Burkholderia cepacia ATCC 17759 could synthesize poly-3-hydroxybutyrate (PHB) from glycerol with concentrations ranging from $3 \%$ to $9 \%(\mathrm{v} / \mathrm{v})$.

\section{Fats, Vegetable Oils and Waste Cooking Oils}

Fatty acids are known to deliver more energy per mole on conversion to PHA as 
compared to carbohydrates (Solaiman et al., 2006b). Until recently, the use of triacylglycerols (TAG) as a feedstock for production of PHA was a challenge, mainly due to its hydrophobic nature and inherent difficulties encountered during the fermentation process. However, Shimamura et al., (1994) demonstrated that Aeromonas caviae was able to biosynthesize PHAs directly from pre-treated (hydrolyzed) TAG. Cromwick et al., (1996) showed that Pseudomonas resinovorans accumulated PHA to upto $15 \%$ of its cell dry weights from tallow. Ashby and Foglia (1998) further investigated PHAs production by $P$ resinovorans using a whole range of TAGs, such as butter oil, lard, coconut oil, olive oil and soybean oil for the production of mcl-PHA. It was observed that the type of monomers had a strong relationship with the type of substrate. Coconut oil containing high levels of saturated fat produced saturated PHA monomers while soybean oil containing high levels of unsaturated fat produced unsaturated PHA monomers. Various bacterial strains belonging to Pseudomonas, Acinetobacter, Sphingobacterium, Brochothrix, Caulobacter, Ralstonia, Burkholderia, and Yokenella genera, that are capable of producing PHB while degrading oil have been isolated from oil contaminated sites (Saharan et al. 2014). Readers can refer to the following articles discussing PHAs production from palm oil (Wu et al., 2009), olive oil (Ntaikou et al., 2009), corn oil (Chaudhry et al., 2011), coconut oil (Thakor et al., 2005), soy bean oil (Kahar et al., 2004) and other vegetable oils and animal fats (Table1).

Table1 Bacteria used for production of PHA from plant oils and wastes

\begin{tabular}{|c|c|c|c|}
\hline Strains & PHA Type & Substrates & References \\
\hline Alcaligenes latus DSM 1124 & PHB & Soya waste, malt waste & Yu et al.,1999 \\
\hline Bacillus megaterium & PHB & Beet molasses, date syrup & Omar et al., 2001 \\
\hline Burkholderia sp. USM (JCM 15050) & PHB & $\begin{array}{l}\text { Palm oil derivatives, fatty acids, } \\
\text { glycerol }\end{array}$ & Chee et al., 2010 \\
\hline Comamonas testosteroni & MCL-PHA & $\begin{array}{l}\text { Castor oil, coconut oil, mustard oil, } \\
\text { cottonseed oil, groundnut oil, olive oil, } \\
\text { sesame oil }\end{array}$ & Thakor et al., 2005 \\
\hline Cupriavidus necator & PHB & Bagasse hydrolysates & Yu and Stahl 2008 \\
\hline Cupriavidus necator $\mathrm{H} 16$ & $\mathrm{P}(3 \mathrm{HB}-\mathrm{co}-3 \mathrm{HV})$ & $\begin{array}{l}\text { Crude palm kernel oil, olive oil, sunflower } \\
\text { oil, palm kernel oil, cooking oil, palm olein, } \\
\text { crude palm oil, coconut oil }+ \text { sodium } \\
\text { propionate }\end{array}$ & Lee et al., 2008 \\
\hline Cupriavidus necator DSM 545 & PHB & Waste glycerol & Cavalheiro et al., 2009 \\
\hline Recombinant Cupriavidus necator & P(3HB-co-3HHx) & $\begin{array}{l}\text { Palm kernel oil, palm olein, crude palm oil, } \\
\text { palm acid oil }\end{array}$ & Loo et al., 2005 \\
\hline Pseudomonas aeruginosa IFO3924 & mcl PHA & Palm oil & Marsudi et al., 2008 \\
\hline Pseudomonas aeruginosa NCIB 40045 & mcl PHA & Waste frying oil & Fernandez et al., 2005 \\
\hline Pseudomonas guezennei biovar. Tikehau & mcl PHA & Coprah oil & Simon-Colin et al., 2008 \\
\hline
\end{tabular}

\section{Wastewater}

Production of PHAs from wastewater provides an economically viable alternative. Various organic wastewaters, such as municipal wastewater (Coats $\boldsymbol{e}$ al., 2011), biodiesel wastewater (Dobroth $\boldsymbol{e t}$ al., 2011), food processing waste effluent (Reddy et al., 2012), brewery waste effluent (Liu et al., 2011) and kraft mill wastewater (Pozo et al., 2012) have been tested for PHAs biosynthesis. Most of the cases involve conversion of organic carbon into volatile fatty acids in aerobic activated sludge in the first step, followed by PHA production using mixing cell cultures in the second step. Although the final PHAs concentrations are still low at the current investigated conditions, PHAs could accumulate to around or even over $50 \%$ of the cell dry weight in some cases (Liu et al., 2011). Vinasse, a highly polluting waste of the ethanol industry was utilized for the production of polyhydroxyalkanoate (PHA) by the extremely halophilic archaeon, Haloferax mediterranei leading to $70 \%$ maximum accumulation of PHA (Bhattacharyya, 2012). The production of PHB by Bacillus subtilis NG220 was observed utilizing the sugar industry waste water supplemented with various carbon and nitrogen sources to yield $5.297 \mathrm{~g} / \mathrm{L}$ of $\mathrm{PHB}$ accumulating $51.8 \%$ ( w/w) of biomass (Singh et al., 2013).

\section{UPSTREAM AND DOWNSTREAM PROCESSING}

A number of fermentation strategies have been reported for the production of PHB. Process selection depends upon the type of culture used, substrates, physiological conditions, fermentation processes and methods employed for the recovery of the final products. This section highlights the various upstream and downstream processes used in PHB production.

\section{Fermentation Strategies}

\section{Pure culture $\mathrm{PHA}$ production}

Pure cultures of PHA producing bacteria can be divided into two groups: 1. Non-growth associated: The non-growth associated PHA producing bacteria, for example $C$. necator and Pseudomonas species require nutrient limitation to accumulate PHA. Biomass growth and PHA accumulation are typically performed in two separate stages: The first stage is associated with biomass growth due to the availability of nutrients. In the second stage, due to the limitation or depletion of one nutrient PHA production prevails
2. Growth associated PHA producing bacteria: These organisms such as Alcaligenes latus and recombinant Escherichia coli don't require nutrient limitation and PHA accumulation and growth occur simultaneously (Lee, 1996b). However, nutrient feeding strategy can be applied to obtaining PHA production in fed-batch process). In fed-batch cultures of growth-associated PHA producing bacteria, a nutrient feeding strategy is essential for obtaining high PHA production yields. This is because both cell growth and PHA synthesis can be enhanced as both processes occur at the same time. The two processes need to be balanced in order to avoid low PHA levels (Khanna and Srivastava, 2005).

\section{Mixed culture PHA production}

Mixed Microbial Cultures (MMC) are defined as group of different microorganisms growing together on the same substrate. Three main processes are used to produce PHA from a mixed culture:

1. Anaerobic-aerobic (AN/AE) process: PHA production using the AN/AE system comprises of three steps. In the first Activated Sludge Treatment Plant (ASTP) is used for culture enrichment. This is followed by fermentations of industrial waste water and agroindustrial residues through acidogenesis into substrate containing Volatile Fatty Acids (VFAs). These VFAs are then used for PHA production (Figure 3). However, under anaerobic conditions, low amounts of PHAs are produced (Satoh $\boldsymbol{e t}$ al., 1996). One of the ways of improving PHA accumulation is to create a micro-aerophilic environment which allows substrate oxidation for increased energy generation (Satoh et al., 1998; Takabatake et al., 2000). 
Culture Enrichment

Raw WW

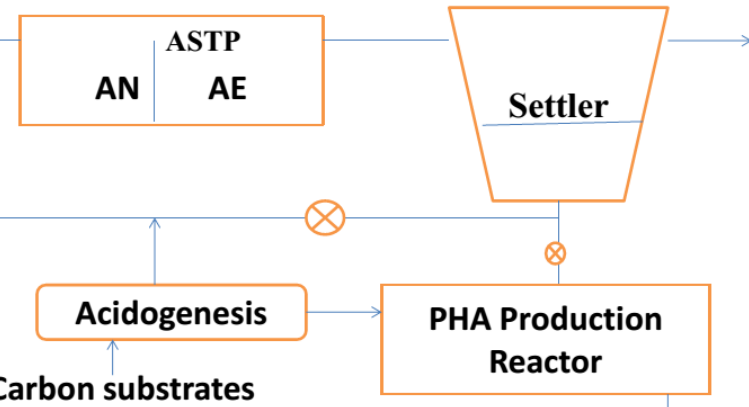

PHA Recovery

Figure 3 Anaerobic-aerobic Process

2. Aerobic dynamic feeding (ADF) system (feast and famine): ADF is the strategy of transient carbon supply where long periods of substrate shortage (famine period) are alternated with short periods of substrate excess (feast period) in a fully aerobic reactor (Figure 4). The PHA production occurs due to an intracellular component limitation. In the long periods of carbon limitation (famine), the macromolecular composition of the cells changes. As a consequence, the microorganisms need a physiological adaptation when they are exposed to high substrate concentrations (feast). Since synthesis of polymers requires less physiological adaptation than cell growth, storage is the faster response to the transient substrate supply (Dias et al., 2005, Daigger and Graddy 1982). Although product is only formed during the feast phase, the famine phase is also very important for the process feasibility. The famine periods should be short in order to obtain high volumetric productivities but on the other hand, they should be long enough to guarantee high and stable PHA storage capacities on the long term (Dias et al., 2005). Glycogen and PHAs are the most prevailing polymers produced using ADF strategy. This is because during the feast phase, substrate uptake rate is very high which results in $\mathrm{NADH}_{2}$ formation which is subsequently converted into ATP through oxidative phosphorylation. Once the ATP requirement for growth processes are satisfied, $\mathrm{NADH}_{2}$ starts accumulating resulting in production of storage polymers. Since, $\mathrm{PHB}$ production is $\mathrm{NADH}$ consuming in contrast to glycogen production. PHB is the most common produced polymer. In such cases, PHB serves as a NADH sink. In depleted carbon source conditions, the accumulated PHB can be utilized as an internal carbon and energy source for growth (van Aalst-van Leeuwen et al., 1997). Only PHA producing organisms can develop during the famine period by degrading the PHA polymer. So during famine periods, cell growth of PHA accumulating organisms is not inhibited but continues at a more or less constant rate and during feast periods, an efficient competition for substrate takes place (Beun et al., 2000). The length of the feast and famine periods must be chosen to allow complete substrate consumption and significant depletion of the accumulated PHA respectively (Paul and Liu, 2012).

\section{Synthetic Substrates}

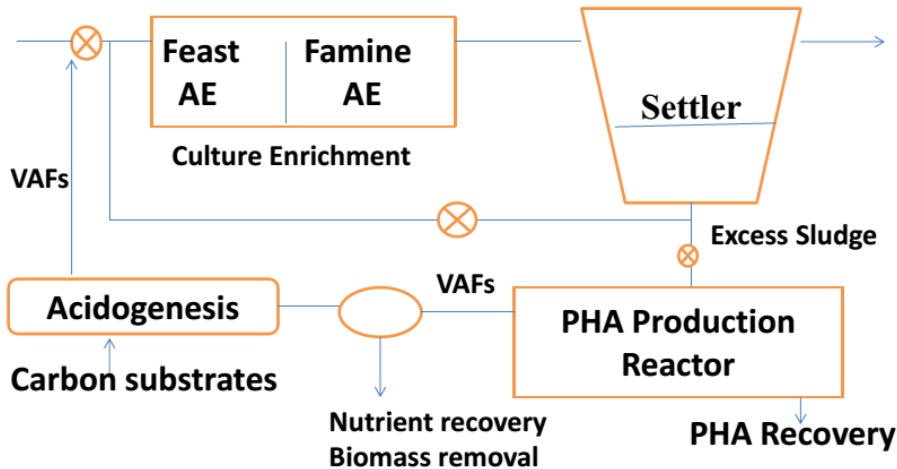

Figure 4 Aerobic Dynamic Feeding System

3. Fed-batch process under nutrient growth limitation: In this strategy, carbon substrate from industrial waste water and organic wastes is fermented through acidogenesis into substrate containing VFAs which are used for PHA production in a fed-batch reactor (Figure 5). The sludge present in the PHA production reacto originates from ASTP in which AN/AE or ADF conditions are established. This strategy can only be applied if the cells are previously formed and PHA accumulation is the only goal. Table 2 outlines the major difference in PHB production by using pure and mixed cultures.

Excess Sludge from ASTP

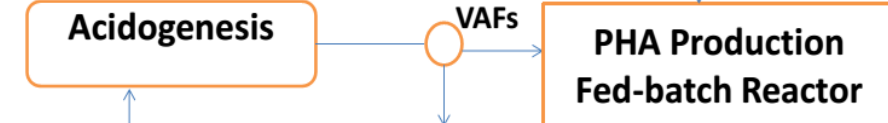 \\ PHA Recovery}

Figure 5 Fed-Batch Process

Table 2 Comparison between Pure culture and Mixed culture PHA production

\begin{tabular}{lcc}
\hline PHA Production & Pure Culture & Mixed Culture \\
\hline Conditions & $\begin{array}{c}\text { External nutrient limitation } \\
\text { Excess carbon source }\end{array}$ & $\begin{array}{c}\text { Internal nutrient } \\
\text { limitation } \\
\text { AN/AE or ADF }\end{array}$ \\
\hline $\begin{array}{l}\text { Substrate } \\
\text { Requirements }\end{array}$ & Single substrate & Waste Materials \\
\hline Growth & Separately & Simultaneously \\
\hline $\begin{array}{l}\text { Media } \\
\text { Requirements }\end{array}$ & Synthetic Media & Complex Media \\
\hline $\begin{array}{l}\text { Reactor } \\
\text { Adviguration }\end{array}$ & $\begin{array}{c}\text { Fed-batch } \\
\text { Higher volumetric } \\
\text { productivity }\end{array}$ & $\begin{array}{c}\text { Sequential Batch } \\
\text { Reactor }\end{array}$ \\
\hline & $\begin{array}{c}\text { Cheap substrates } \\
\text { Expensive Substrate }\end{array}$ & $\begin{array}{c}\text { Low volumetric } \\
\text { productivity }\end{array}$ \\
\hline Disadvantages & maintaining aseptic operation & pequipment for
\end{tabular}

\section{DOWNSTREAM PROCESSING}

Since PHA is an intracellular product, the method applicable for the effective separation of PHA from other biomass components can be complex and costly. Various methods have been reported for the recovery and purification of PHAs from biomass:

Solvent Extraction: This is the most commonly used method for the extraction of PHA from biomass. Among various solvents, chloroform is the most preferred solvent to carry out PHA extraction without its degradation (Hahn et al., 1995). Other halogenated hydrocarbon solvents such as dichloromethane, dichlorethane and chloropropane can be also used to extract and purifiy PHA from the cell biomass though these solvents can be potentially hazardous to health and environment (Ramsay et al., 1994).

Cell lysis by Sodium hypochloride: In this method, the cell biomass is initially treated with sodium hypochlorite solution before the PHA granules are isolated from the cell debris by centrifugation (Berger et al., 1989). The use of sodium hypochlorite to extract PHA from biomass always results in severe degradation of PHA and yields PHA with a lower molecular weight (MW). In contrast, the use of surfactant pretreatment to recover PHA results in lower purity but less degradation of MW.

Enzymatic digestion: is a gentle but a selective separation method. Enzymes such as proteases (trypsin, chymotrypsin, rennin, papain and bromelain), cellulases and lysozyme, are commonly used in this method (de Koning and Witholt 1997). Specificity of enzymes and mild operational conditions employed result in high reaction rates with little product damage. However, this recovery process requires that the culture broth should be provided with a short period of heat shock treatment before the enzymatic treatment so as to rupture the cells as well as denature and solubilize the nucleic acids. Without this preliminary heating step, the release of nucleic acid into the medium will result in a very viscous suspension (Kapritchkoff et al., 2006).

\section{CONCLUSION}

As discussed in the preceding sections, raw material cost is one of the major reasons for the high price of PHAs. This necessitates the use of various cheap carbon sources for the PHAs production. However, the major challenge in using 
these substrates is the low fermentation efficiency and final PHAs concentration of these fermentations which leads to an increasing cost in product separation and purification. It has been observed that a change in the substrate from pure sugars to agro-industrial residues does not compromise with the properties of the PHAs Therefore, the selection of the substrate should be made based on balanced considerations keeping in view the efficiency, costs and sustainability of the final product.

Conflict of Interest: All authors have no conflict of interest to report

\section{REFERENCES}

Aarthi, N., \& Ramana, K.V. (2011). Identification and Characterization of Polyhydroxybutyrate producing Bacillus cereus and Bacillus mycoides strains. Int J Environ Sci,5,744-756

Ahn, W.S., Park, S.J., \& Lee, S.Y. (2000). Production of poly (3Hydroxybutyrate) by fed-batch culture of recombinant Escherichia coli with a highly concentrated whey solution. Appl Environ Microb, 66,3624-7, PMID:10919830

Akiyama, M., Tsuge, T., \& Doi, Y. (2003). Environmental life cycle comparison of biodegradable plastic, poly $\beta$-hydroxybutyrate. Bioresource Technol, 98, 3579 84.

Albuquerque, M.G.E., Eiroa, M., Torres, C., Nunes, B.R., \& Reis, M.A. (2007) Strategies for the development of a side stream process for polyhydroxyalkanoate (PHA) production from sugar cane molasses. J Biotechnol ,130,411-21 http://dx.doi.org/10.1016/j.jbiotec.2007.05.011

Arshad, M.U., Jamil, N., Naheed, N., \& Hasnain, S. (2007). Analysis of bacterial strains from contaminated and non-contaminated sites for the production of biopolymers. Afr J Biotechnol, 6(9),1115-1121

Ashby, R.D., \& Foglia, T.A. (1998). Poly(hydroxyalkanoate) biosynthesis from triglyceride substrates. Appl Microbiol Biot, 49, 431-7 http://dx.doi.org/10.1007/s002530051194

Ashby, R.D. (2005). Synthesis of short-medium-chain-length poly (hydroxyalkanoate) blends by mixed culture fermentation of glycerol. Biomacromolecules, 6,2106-12 http://dx.doi.org/10.1021/bm058005h

Ashby, R.D., Solaiman, D.K.Y., \& Foglia, T.A. (2004). Bacterial poly (hydroxyalkanoate) polymer production from the biodiesel co product stream. $J$ $\begin{array}{lll}\text { Polym Environ } & 12 \\ \text { http://dx.doi.org/10.1023/B:JOOE.0000038541.54263.d9 }\end{array}$

Baei, M.S., Najafpour, G.D., \& Lasemi, Z. (2010). Optimization of PHAs production from dairy industry wastewater (cheese whey) by Azohydromonas lata DSMZ 1123, Iranica J Energ Environ,1(2),132-136

Belal, E.B. (2013). Production of Poly- $\beta$-Hydroxybutyric Acid (PHB) by Rhizobium elti and Pseudomonas stutzeri. Curr Res J Biol Sci,5(6), 273-284 Bengtsson, S., Pisco, A.R., Reis, M.A., \& Lemos, P.C. (2010). Production of polyhydroxyalkanoates from fermented sugar cane molasses by a mixed culture enriched in glycogen accumulating organisms. J Biotechnol, 145,253-63 http://dx.doi.org/10.1016/j.jbiotec.2009.11.016

Berger, E., Ramsay, B.A., Ramsay, J.A., Chavarie, C., \& Braunegg, G. (1989) PHB Recovery by hypochlorite digestion of non-PHB biomass. Biotechnol Technol, 3,227-232 http://dx.doi.org/10.1007/BF01876053

Bertrand, J-L., Ramsay, B.A., Ramsay, J.A., \& Chavarie, C. (1990). Biosynthesis of Poly- $\beta$-Hydroxyalkanoates from Pentoses by Pseudomonas pseudoflava. Appl Environ Microb ,56,3133-8

Beun, J., Paletta, F., van Loosdrecht, M., \& Heijnen, J.J. (2000). Stoichiometry and kinetics of poly-beta-hydroxybutyrate metabolism in aerobic, slow growing activated sludge cultures. Biotechnol Bioeng, 67 (4), 379-389.

Bhattacharyya, A., Pramanik, A., Maji, S.K., Haldar, S., Mukhopadhyay, U.K., \& Mukherjee, J. (2012). Utilization of vinasse for production of poly-3(hydroxybutyrate-co-hydroxyvalerate) by Haloferax mediterranei. AMB Express, 2(1),34. doi, 10.1186/2191-0855-2-34. http://dx.doi.org/10.1186/2191-0855-2-34 Bioplastics. (2012). General Political Strategies. http,//en.europeanbioplastics.org/press/press-pictures/labelling-logos-charts/. European Bioplastics Bormann, E.J., \& Roth, M. (1999). The production of polyhydroxybutyrate by Methylobacterium rhodesianum and Ralstonia eutrophain media containing glycerol and casein hydrolysates. Biotechnol Lett, 21,1059-63.

Cavalheiro, J.M.B.T., de Almeida, M.C.M.D., Grandfils, C., \& Dafonseca, M.M.R. (2009). Poly(3-hydroxybutyrate) production by Cupriavidus necator using waste glycerol. Process Biochem, 44,509-515 http://dx.doi.org/10.1016/j.procbio.2009.01.008

Cesário, M.T., Raposo, R.S., de Almeida, M.C., van Keulen, F., Ferreira, B.S., \& da Fonseca, M.M. (2014). Enhanced bioproduction of poly-3-hydroxybutyrate from wheat straw lignocellulosic hydrolysates. New Biotechnology ,31(1),104113.

Chaijamrus, S., \& Udpuay, N. (2008). Production and characterization of polyhydroxybutyrate from molasses and corn steep liquor produced by Bacillus megaterium ATCC 6748. Agric Eng Int, The CIGR J,10,1-12.

Chaudhry, W., Jamil, N., Ali, I., Ayaz, M.H., \& Hasnain, S. (2011). Screening for polyhydroxyalkanoate (PHA)-producing bacterial strains and comparison of
PHA production from various inexpensive carbon sources. Ann Microbiol, 61 623-9. http://dx.doi.org/10.1007/s13213-010-0181-6

Chee, J.Y., Tan, Y., Samian, M.R., \& Sudesh, K. (2010). Isolation and characterization of a Burkholderia sp. USM (JCM15050) capable of producing polyhydroxyalkanoate (PHA) from triglycerides, fatty acids and glycerols. $J$ Polym Environ, 18,584-592. http://dx.doi.org/10.1007/s10924-010-0204-1

Chen, G.Q., \& Page, W.J. (1997.) Production of poly-b-hydroxybutyrate by Azotobacter vinelandiin a two-stage fermentation process. Biotechnol Tech ,11,347-50.

Chenyu, D., Julia, S., Wim, S., \& Lin, S.K.C. (2012). Polyhydroxyalkanoates Production From Low-cost Sustainable Raw Materials. Curr Chem Biol, 6 (1), 1425.

Coats, E.R., VandeVoort, K.E., Darby, J., \& Loge, F.J. (2011). Toward Polyhydroxyalkanoate Production Concurrent with Municipal Wastewater Treatment in a Sequencing Batch Reactor System. J Environ Eng, 137,46-54. http://dx.doi.org/10.1061/(ASCE)EE.1943-7870.0000302

Cromwick, A.M., Foglia, T., \& Lenz, R.W. (1996). The microbial production of poly (hydroxyalkanoates) from tallow. Appl Microbiol Biot, 46, 464-9. http://dx.doi.org/10.1007/s002530050845

da Silva, G.P., Mack, M., \& Contiero, J. (2009). Glycerol, A promising and abundant carbon source for industrial microbiology. Biotechnology Adv, 27, 30 39. http://dx.doi.org/10.1016/j.biotechadv.2008.07.006

Daigger, G., \& Graddy, C. (1982). An assessment of the role of physiological adaptation in the transient response of bacterial cultures. Biotechnol Bioeng, 24,1427-1444. http://dx.doi.org/10.1002/bit.260240614

David, J.K., Subbiah, P.G., Sukumar, A., \& Thiyagarajan, K. (2013). Biosynthesis of polyhydroxybutyrates from Azotobacter chroococcum using cheaper substrates under different optimal conditions. World J Pharm Res,2(6), 2396-2404.

Day, R.H., Shaw, D.G., \& Ignell, S. (1989). The quantitative distribution and characteristics of neuston plastic in the North Pacific Ocean, Proceedings of the Second International Conference on Debris. 1985-1988.

deKoning, G.J.M., \& Witholt, B. (1997). A process for the recovery of poly (hydroxyalkanoates) from Pseudomonas Part 1, Solubilization. Bioprocess Eng,17,7-13.

Dias, J., Seram, L., Lemos, P.C., Reis, M.A., \& Oliveira. (2005). Mathematica Modelling of a Mixed Culture Cultivation Process for the Production of Polyhydroxybutyrate. Biotechnol Bioeng volume 92. Wiley Periodicals, Inc http://dx.doi.org/10.1002/bit.20598

Dobroth, Z.T., Hu, S., Coats, E.R., \& McDonald, A.G. (2011) Polyhydroxybutyrate synthesis on biodiesel wastewater using mixed microbial $\begin{array}{llll}\text { consortia. } & \text { BioresourceTechnol, } & 102, & 3352-3359\end{array}$ http://dx.doi.org/10.1016/j.biortech.2010.11.053

Doi, Y. (1990). Microbial Polyesters. VCH Publisher,Weinheim, Cambridge, NewYork

Fernandez, D., Rodriguez, E., Bassas, M., Vinas, M., Solanas, A.M., Llorens, J., Marques', A.M., \& Manresa, A. (2005). Agro-industrial oily wastes as substrates for PHA production by the new strain Pseudomonas aeruginosa NCIB 40045 , Effect of culture conditions. Biochem Eng, 26,159-167. http://dx.doi.org/10.1016/j.bej.2005.04.022

Findlay, R.H., \& White, D.C. (1983). Polymeric beta-hydroxyalkanoates from environmental samples and Bacillus megaterium. Appl Environ Microbiol, 45(1), 71-78.

Fonseca, G.G., \& Antonio, R.V. (2006). Polyhydroxyalkanoates production by recombinant Escherichia coli harboring the structural genes of the polyhydroxyalkanoate synthases of Ralstonia eutropha and Pseudomonas aeruginosa using low cost substrate. J Appl Sci ,6,1745-1750

Fukui, T., \& Doi, Y. (1998). Efficient production of polyhydroxyalkanoates from plant oils by Alcaligenes eutrophus and its recombinant strain. Microbio Biotechnol ,49, 333-336. http://dx.doi.org/10.1007/s002530051178

Full, T.D., Jung, D.O., \& Madigan, M.T. (2006). Production of polyhydroxyalkanoates from soy molasses oligosaccharides by new, rapidly growing Bacillus species. Lett Appl Microbiol, 43,377-384.

Ghate, B., Pandit, P., Kulkarni, C., Mungi, D.D., \& Patel, T.S. (2011). PHB production using novel agro-industrial sources from different Bacillus species. Int J Pharm Biosci, 2(3),242-249

Gouda, M.K., Swellam, A.E., \& Omar, S.H. (2001). Production of PHB by a Bacillus megaterium strain using sugarcane molasses and corn steep liquor as sole carbon and nitrogen sources. Microbiol Res, 156, 201-207. http://dx.doi.org/10.1078/0944-5013-00104

Hahn, S., Chang, Y., \& Lee, S. (1995). Recovery and characterization of poly(3hydroxybutyric acid) synthesized in Alcaligenes eutrophus and recombinant Escherichia coli. Appl Environ Microbiol,61, 34-39

Hamieh, A., Olama, Z., \& Holail, H. (2013). Microbial production of polyhydroxybutyrate, analysis in Azospirillum brasilence. Can J Microbol, 41,73-76.

Han, J., Hou, J., \& Liu, H. (2010). Wide distribution among halophilic archaea of a novel polyhydroxyalkanoate synthase subtype with homology to bacterial type III synthases. Appl Environ Microb, 76, 7811-7819. http://dx.doi.org/10.1128/AEM.01117-10 
Hassan, M.A., Shirai, Y., Kusubayashi, N., Karim, M.I.A., Nakanishi, K., \& Hashimoto, K. (1997). Production of polyhydroxyalkanoate from anaerobically treated palm oil mill effluent by Rhodobacter sphaeroides. J Ferment Bioeng, 83,485 - 488. http://dx.doi.org/10.1016/S0922-338X(97)83007-3

Huang, T.Y., Duan, K.J., Huang, S.Y., \& Chen, C.W. (2006). Production of polyhydroxyalkanoates from inexpensive extruded rice bran and starch by Haloferax mediterranei. J Ind Microbiol Biotechnol, 33(8),701-706. http://dx.doi.org/10.1007/s10295-006-0098-z

Jau, M.H., Yew, S.P., Toh, P.S., Chong, A.S., Chu, W.L., Phang, S.M., Najimudin, N., \& Sudesh, K. (2005). Biosynthesis and mobilization of poly,3hydroxybutyrate) $[\mathrm{P}(3 \mathrm{HB})]$ by Spirulina platensis. Int J Biol Macromol, 36,144 151. http://dx.doi.org/10.1016/j.ijbiomac.2005.05.002

Kahar, P., Tsuge, T., Taguchi, K., \& Doi, Y. (2004). High yield production of polyhydroxyalkanoates from soybean oil by Ralstonia eutropha and its recombinant strain. Polym Degrad Stabil, 83, 79-86. http://dx.doi.org/10.1016/S0141-3910(03)00227-1

Kapritchkoff, F.M., Viotti, A.P., Alli, R.C., Zuccolo, M., Pradella, J.G., Maiorano, A.E., Miranda, E.A., \& Bonomi, A. (2006). Enzymatic recovery and purification of polyhydroxybutyrate produced by Ralstonia eutropha. J Biotechnol,122,453-462. http://dx.doi.org/10.1016/i.jbiotec.2005.09.009

Keenan, T.M., Nakas, J.P., \& Tanenbaum, S.W. (2006). Polyhydroxyalkanoate copolymers from forest biomass. $J$ Ind Microbiol, 33, 616-26. http://dx.doi.org/10.1007/s10295-006-0131-2

Khanna, S., \& Srivastava, A.K. (2005). Recent advances in microbial polyhydroxyalkanoates. Process Biochem, 40,607-619. http://dx.doi.org/10.1016/j.procbio.2004.01.053

Khardenavis, A.A., Suresh Kumar, M., Mudliar, S.N., \& Chakrabarti, T. (2007) Biotechnological conversion of agro-industrial wastewaters into biodegradable plastic, poly $\beta$-hydroxybutyrate. Bioresour Technol ,98 (18), 3579-3584 http://dx.doi.org/10.1016/j.biortech.2006.11.024

Koller, M., Bona, R., \& Chiellini, E. (2008). Polyhydroxyalkanoate production from whey by Pseudomonas hydrogenovora. BioresourTechnol, 99, 4854-63. http://dx.doi.org/10.1016/j.biortech.2007.09.049

Koller, M., Hesse, P., Salerno, A., Reiterer, A., \& Braunegg, G. (2011). Viable antibiotic strategy against microbial contamination in biotechnological production of polyhydroxyalkanoates from surplus whey. Biomass Bioenerg, 35 748-53. http://dx.doi.org/10.1016/j.biombioe.2010.10.008

Kosior, E., Braganca, R.M., \& Fowler, P. (2006). Lightweight Compostable Packaging, Literature Review. The Waste \& Resources Action Programme, Banbury, Oxon 18-20

Kulpreecha, S., Boonruangthavorn, A., Meksiriporn, B., \& Thongchul, N. (2009). Inexpensive fed-batch cultivation for high poly(3-hydroxybutyrate) production by a new isolate of Bacillus megaterium. J Biosci Bioeng, 107, 240-245. http://dx.doi.org/10.1016/j.jbiosc.2008.10.006

Latha, D., Sandya, Shahina, \& Rekha. (2013). Biopolymer Production Using Pseudomonas Sp. (MTCC) and its Application in Agriculture. Am J Biochem Molec, 3,293-303. http://dx.doi.org/10.3923/ajbmb.2013.293.303

Lovett, R. A. (2010). Huge Garbage Patch Found in Atlantic Too. National Geographic News. National Geographic Society.

Law, K.H., Leung, Y.C., Lawford, H., Chua, H., Wai-Hung, L., \& Yu, P.H. (2001). Production of polyhydroxybutyrate by Bacillus species isolated from municipal activated sludge. Appl Biochem Biotech, 91-93, 515-522. http://dx.doi.org/10.1385/ABAB:91-93:1-9:515

Lee, S. (1996a). Review Bacterial Polyhydroxyalkanoates. Biotechnol Bioeng 49, $1-14$

Lee, S. (1996b). Plastic bacteria? Progress and prospects for polyhydroxyalkanoate production in bacteria. Trends Biotechnol, 14 (11), 431 438. http://dx.doi.org/10.1016/0167-7799(96)10061-5

Lee, S.Y., Middelberg, A.P.J., \& Lee, Y.K. (1997). Poly (3-hydroxybutyrate) production from whey using recombinant Escherichia coli. Biotechnol Lett, 19, 1033-1035

Lee, W.H., Loo, C.Y., Nomura, C.T., \& Sudesh, K. (2008). Biosynthesis of polyhydroxyalkanoate copolymers from mixtures of plant oils and 3hydroxyvalerate precursors. Bioresour Technol, 99,6844-6851. http://dx.doi.org/10.1016/j.biortech.2008.01.051

Lemoigne, M. (1926). Produits deshydration et de polymerization de lacide $\beta$ oxybutyrique. Bull Soc Chim Bio, 8,770-782

Lillo, J.G., \& Rodriguez-Valera, F. (1990). Effects of culture conditions on poly( $\beta$-hydroxybutyric) acid production by Haloferax mediterranei. Appl Environ Microb, 56, 2517-2521

Lin, C.S.K., Luque, R., Clark, J.H., Webb, C., \& Du, C. (2012). Wheat-based biorefining strategy for fermentative production and chemical transformations of succinic acid. Biofuels Bioprod Bior, 6, 88-104.

Liu, H.Y., VanderGheynst, J.S., Darby, J.L., Thompson, D.E., Green, P.G., \& Loge, F. (2011). Factorial experimental designs for enhancement of concurrent poly(hydroxyalkanoate) production and brewery wastewater treatment. Water Environ Res, 83, 36-43. http://dx.doi.org/10.2175/106143010X12681059116932

Loo, C.Y., Lee, W.H., Tsuge, T., Doi, Y., \& Sudesh, K. (2005). Biosynthesis and characterization of poly (3-hydroxybutyrate-co-3-hydroxyhexanoate) from palm oil products in a Wautersia eutropha mutant. Biotechnol Lett,27,1405-1410 http://dx.doi.org/10.1007/s10529-005-0690-8

Madison, L.L., \& Huisman, G.W. (1999). Metabolic engineering of poly (3hydroyalkanoates), from DNA to plastic. Microbiol Mol Biol, $R$ 63,21-53

Marangoni, C., Furigo Jr, A., \& de Aragão, G.M.F. (2002). Production of poly (3-hydroxybutyrate-co-3-hydroxyvalerate) by Ralstonia eutropha in whey and inverted sugar with propionic acid feeding. Process Biochem, 38, 137-41. http://dx.doi.org/10.1016/S0032-9592(01)00313-2

Marsudi, S., Unno, H., \& Hori, K. (2008). Palm oil utilization for the simultaneous production of polyhydroxyalkanoates and rhamnolipids by Pseudomonas aeruginosa. Appl Microbiol Biotechnol, 78,955-961. http://dx.doi.org/10.1007/s00253-008-1388-3

Naheed, N., Jamil, N., Hasnain, S., \& Abbas, G. (2012). Biosynthesis of polyhydroxybutyrate in Enterobactersp. SEL2 and Enterobacteriaceae bacterium sp. PFW1 using sugar cane molasses as media. Afr J Biotechnol, 11(16), 3321 3332.

Nath, A., Dixit, M., Bandiya, A., Chavda, S., \& Desai, A.J. (2008). Enhanced PHB production and scale up studies using cheese whey in fed batch culture of Methylobacterium sp. ZP 24. Bioresour Technol, 99, 5749-55

Ntaikou, I., Kourmentza, C., \& Koutrouli, E.C. (2009). Exploitation of olive oil mill wastewater for combined biohydrogen and biopolymers production. $\begin{array}{llll}\text { Bioresource Technol, } & \text { 3724-30. }\end{array}$ http://dx.doi.org/10.1016/j.biortech.2008.12.001

Obruca, S., Marova, I., Melusova, S., \& Mravcova, L. (2011). Production of polyhydroxyalkanoates from cheese whey employing Bacillus megaterium CCM 2037. Ann Microbiol, 61, 947-953. http://dx.doi.org/10.1007/s13213-011-0218-5 Omar, S., Rayes, A., Eqaab, A., Voß, I., \& Steinbüchel, A. (2001). Optimization of cell growth and poly(3-hydroxybutyrate) accumulation on date syrup by a Bacillus megaterium strain. Biotechnol Lett, 23,1119-1123

Page, W.J. \& Knosp, O. (1989) Hyperproduction of Poly- $\beta$-Hydroxybutyrate during Exponential Growth of Azotobacter vinelandii UWD. Appl Environ Microbiol, 55(6), 1334-1339

Page, W.J. (1992). Production of polyhydroxyalkanoates by Azotobacter vinelandii UWD in beet molasses culture. FEMS Microbiol Rev, 103, 149-57

Pantazaki, A.A., Papaneophytou, C.P., Pritsa, A.G., Liakopoulus-Kyriakides, M., \& Kyriakidis, D.A. (2009). Production of polyhydroxyalkanoates from whey by Thermus thermophilus HB8. Process Biochem, 44,847-853 http://dx.doi.org/10.1016/j.procbio.2009.04.002

Paul, E., \& Liu, Y. (2012). Biological Sludge Minimization and Biomaterials/Bioenergy Recovery Technologies (First ed.), John Wiley \& Sons Inc, USA, pp. 465-498. http://dx.doi.org/10.1002/9781118309643

Peoples, O.P., \& Sinskey, A.J. (1989). Poly $\beta$-hydroxybutyrate (PHB) biosynthesis in Alcaligens eutrophus H16, Identification and characterization of PHB polymerase gene (PhbC). J Biol Chem,264, 15298-15303

Povolo, S., \& Casella, S. (2003). Bacterial production of PHA from lactose and cheese whey permeates. Macromol Symp, 197(1),1-10. http://dx.doi.org/10.1002/masy.200350701

Pozo, G., Villamar, A.C., Martínez, M., \& Vidal, G. (2011) Polyhydroxyalkanoates (PHA) biosynthesis from kraft mill wastewaters, Biomass origin and C,N relationship influence. Water Sci Technol,63, 449-55. http://dx.doi.org/10.2166/wst.2011.242

Preethi, R., Sasikala, P., \& Aravind, J. (2012). Microbial production of polyhydroxyalkanoate (PHA) utilizing fruit waste as a substrate. Res Biotechnol,3(1), 61-69

Patel, S.S. (2014). Production of Polyhydroxybutyrate using agro-industrial waste by Psuedomonas aeruginosa. International Journal of Innovation and Scientific Research, 3(2), 102-110.

Ramadas, N.V., Sudheer, S.K., Carlos, R.S., \& Pandey, A. (2009) Polyhydroxybutyrate production using agro-industrial residue as substrate by Bacillus sphaericus NCIM 5149. Braz Arch Biol Technol,52(1),17-23. http://dx.doi.org/10.1590/S1516-89132009000100003

Ramsay, J.A., Berger, E., Voyer, R., Chavarie, C., \& Ramsay, B.A. (1994) Extraction of poly-3 hydroxybutyrate using chlorinated solvents. Biotechnol Tech, 8,589-594. http://dx.doi.org/10.1007/BF00152152

Reddy, V.M., \& Venkatamohan, S. (2012). Influence of aerobic and anoxic microenvironments on polyhydroxyalkanoates (PHA) production from food waste and acidogenic effluents using aerobic consortia. Bioresour Technol, 103, 313-321

Rehm, B.H.A. (2003). Polyester synthases, Natural catalysts for plastics. Biochem J, 376, 15-33. http://dx.doi.org/10.1042/bj20031254

Saharan, B.S., Grewal,A.,\& Kumar,P.(2014). Biotechnological Production of Polyhydroxyalkanoates: A Review on Trends and Latest Developments. Chinese Journal of Biology, Article ID 802984, http://dx.doi.org/10.1155/2014/802984 Saha, S.P., Patra, A., Ghosh, P.B., \& Paul, A.K. (2013). Accumulation of polyhydroxyalkanoic acids by Azotobacter chroococcum mal-201 from organic waste. J Microbiol Biotechnol Food Sci, 3 (1), 44-48

SatheshPrabu, C., \& Murugesan, A.G. (2010). Effective utilization and management of coir industrial waste for the production of poly- $\beta$ hydroxybutyrate (PHB) using the bacterium Azotobacter beijerinickii. Int $J$ Environ Res, 4(3), 519-524 
Satoh, H., Mino, T., \& Matsuo, T. (1998). Anaerobic uptake of glutamate and aspartate by enhanced biological phosphorus removal activated sludge. Water Sci Technol, 37 (4-5), 579-582. http://dx.doi.org/10.1016/S0273-1223(98)00163-2 Senior, P.J., Beech, G.A., Ritchiet, G.A.F., \& Dawes, E.A. (1972). The role of oxygen limitation in the formation of poly- $\beta$-hydroxybutyrate during batch and continuous culture of Azotobacter beijerinckii. Biochem J, 128,1193-1201

Shah, K.R. (2014). Optimization and production of Polyhydroxybutarate (PHB) by Bacillus subtilis G1S1 from soil. Int J Curr Microbiol App Sci, 3(5), 377-387 Shimamura, E., Kasuya, K., Kobayashi, G., \& Doi, Y. (1994). Physical properties and biodegradability of microbial poly (3-hydroxybutyrate-co-3hydroxyhexanoate) Macromolecules,27, 878-80 http://dx.doi.org/10.1021/ma00081a041

Shivakumar, S. (2012). Polyhydroxybutyrate (PHB) production using agroindustrial residue as substrate by Bacillus thuringiensis IAM 12077. Int J Chem Tech Res, 4(3), 1158-1162.

Simon-Colin, C., Raguenes, G., Crassous, P., Moppert, X., \& Guezennec, J. (2008). Novel mcl-PHA produced on coprah oil by Pseudomonas guezenne biovar. tikehau, isolated from a "kopara" mat of French Polynesia. Int J Biol Macromolecules, 43,176-181. http://dx.doi.org/10.1016/j.ijbiomac.2008.04.011

Singh, G., Kumari, A., Mittal, A., Yadav, K., \& Aggarwal, N.K. (2013). Poly $\beta$ Hydroxybutyrate production by Bacillus subtilis NG220 using sugar industry waste water. BioMed Res Int, Article ID 952641, doi.org/10.1155/2013/952641

Solaiman, D.K.Y., Ashby, R.D., Hotchkiss, A.T., \& Foglia, T.A. (2006a) Biosynthesis of medium-chain-length Poly (hydroxyalkanoates) from soy molasses. Biotechnol Lett, 28, 157-162. http://dx.doi.org/10.1007/s10529-0055329-2

Solaiman, D.K.Y., Ashby, R.D., Foglia, T.A., \& Marmer, W.N. (2006b) Conversion of agricultural feedstock and co-products into poly (hydroxyalkanoates). Appl Microbiol Biotechnol, 71, 783-789.

Stockdale, H., Ribbons, D.H., \& Dawes, E.A. (1968). Occurrence of poly- $\beta$ hydroxybutyrate in the Azotobacteriaceae. J. Bacteriol, 95(5), 1798-1803

Sudesh, K., Abe, H., \& Doi, Y. (2000). Synthesis, structure and properties of polyhydroxyalkanoates, Biological polyesters. Prog Polym Sci,25,1503-1555. http://dx.doi.org/10.1016/S0079-6700(00)00035-6

Sudesh, K., Taguchi, K., \& Doi, Y. (2001). Can cyanobacteria be a potential PHA producer? RIKEN Review, 42,75-76

Sujatha, K., \& Shenbagarathai, R. (2006). A study on medium chain length polyhydroxyalkanoate accumulation in Escherichia coli harbouring phaC1 gene of indigenous Pseudomonas sp. LDC-5. Lett Appl Microbiol, 43, 607-614. http://dx.doi.org/10.1111/j.1472-765X.2006.02016.x

Suzuki, T., Yamane, T., \& Shimizu, S. (1986). Mass production of poly-betahydroxybutyric acid by fed-batch culture with controlled carbon/nitrogen feeding. Appl Microbiol Biotechnol, 24, 370-374

Sharma,L., \& Mallick,N. (2005). Enhancement of poly- $\beta$-hydroxybutyrate accumulation in Nostoc muscorumunder mixotrophy, chemoheterotrophy and limitations of gas-exchange. Biotechnol Lett, 27(1), 59-62, 2005.

Takabatake, H., Satoh, H., Mino, T., \& Matsuo, T. (2000). Recovery of biodegradable plastics from activated sludge process. Water Sci Technol,42 (3-4), 351-356.

Tekin, E., Ates, M., \& Kahraman, O. (2012).Poly-3-hydroxybutyrate-producing extreme halophilic archaeon, Haloferax sp. MA10 isolated from Çamaltı Saltern, İzmir. Turk J Biol, 36, 303-312

Thakor, N., Trivedi, U., \& Patel, K.C. (2005). Biosynthesis of medium chain length poly (3-hydroxyalkanoates) (mcl-PHAs) by Comamonas testosterone during cultivation on vegetable oils. Bioresour Technol, 96,1843-1850

Tombolini, R., \& Nuti, M.P. (1989). Poly ( $\beta$-hydroxyalkanoate) biosynthesis and accumulation by different Rhizobium species. FEMS Microbiol Lett, 60,299-304. http://dx.doi.org/10.1016/0378-1097(89)90414-X

Tripathi, A.D., Yadav, A., Jha, A., \& Srivastava, S.K. (2012). Utilizing of sugar refinery waste (cane molasses) for production of bioplastic under submerged fermentation process. J Polm Environ, 20(2), 446-453

van Aalst-van Leeuwen, M., Pot, M., van Loosdrecht, M., \& Heijnen, J.J. (1997). Kinetic modeling of poly( $\beta$-hydroxybutyrate) production and consumption by Paracoccus pantotrophus under dynamic substrate supply. Biotechnol Bioeng, 55, 773-782

Van-Thuoc, D., Quillaguamn, J., Mamo, G., \& Mattiasson, B., (2008) Utilizationof agricultural residues for poly(3-hydroxybutyrate) production by Halomonas boliviensis LC1. J Appl Microbiol, 104, 420-8. http://dx.doi.org/10.1111/j.1365-2672.2007.03553.x

Vollbrecht, D., \& Schlegel, H. (1979). Excretion of metabolites of hydrogen bacteria, 3d(-)-3-hydroxybutanoate. Eur J Appl Microbiol Biotechnol, 7 (3), 259 266

Wu, T.Y., Mohammad, A.W., Jahim, J.M., \& Anuar, N. (2009). A holistic approach to managing palm oil mill effluent (POME), Biotechnological advances in the sustainable reuse of POME. Biotechnol Adv, 27, 40-52. http://dx.doi.org/10.1016/j.biotechadv.2008.08.005

Yu, J., \& Stahl, H. (2008). Microbial utilization and biopolyester synthesis of bagasse hydrolysates. Bioresour Technol, 99,8042- 8048. http://dx.doi.org/10.1016/j.biortech.2008.03.071
Yu, P.H., Chua, H., Huang, A.L., \& Ho, K.P. (1999). Conversion of industrial food wastes by Alcaligenes latus into polyhydroxyalkanoates. Appl Biochem Biotechnol 78,445-454. http://dx.doi.org/10.1385/ABAB:78:1-3:445

Zhang, H., Obias, V., Gonyer, K., \& Dennis, D. (1994). Production of polyhydroxyalkanoates in sucrose-utilizing recombinant Escherichia coli and Klebsiella strains. Appl Environ Microb, 60, 1198-1205

Zhang, Y., Sun, W., Wang, H., \& Geng, A. (2013). Polyhydroxybutyrate production from oil palm empty fruit bunch using Bacillus megaterium R11. Bioresour Technol,147,

$307-314$ http://dx.doi.org/10.1016/i.biortech.2013.08.029

Zhu, C., Nomura, C.T., Perrotta, J.A., Stipanovic, A.J., \& Nakas, J.P. (2010) Production and characterization of poly-3-hydroxybutyrate from biodieselglycerol by Burkholderia cepacia ATCC 17759. Biotechnol Prog, 26(2), 424 430 